Islamic Heritage Architecture and Art II 233

\title{
SEARCHING FOR SPATIAL INFLUENCES OF ISLAMIC BELIEFS ON THE TRADITIONAL TURKISH HOUSE
}

\author{
FERAN ÖZGE GÜVEN ULUSOY, BERNA ÜSTÜN \& FATMA KOLSAL \\ Architecture Department, Anadolu University, Turkey
}

\begin{abstract}
It is possible to say that the concept of a "Turkish House" is mainly a product of Islam, although the form of dwelling tents in the nomadic period indicates there are some common features with a Turkish house. The religion of Islam and the culture of the Turks in Middle Asia show great integration in the Turkish house. The matriarchal family system of the ancient Turks, before they adopted Islam, was inverted to a patriarchal social order such that it affected the traditional Turkish house. Turkish houses mainly show common socio-cultural aspects affected by religious precepts and execute identical features, depending on the region. Thus, it is important to emphasize that the male-dominated belief of the Turco-Islamic family had not changed until the modern period; and the position of women in the society and the house mostly determines the character of a Turkish house. Religious beliefs bring an introverted form and privacy within the Turkish house; because in Islam, cultural privacy of the family members from the others and from the street is important. In addition to that, the privacy of the women family members or guests in the house is most significant; so the privacy, position and actions of the women in Islam is the most important factor shaping the spatial organization of the house. The traces and reflections of Islam can be directly read into spaces such as the haremlik and selamllk, the orientation of the rooms; and the architectural elements such as the windows, doors or some specialized ones; the relationship between streets and the house, the characteristics of courtyard walls, the location of the toilet, the separation of actions and spaces for toilet and bath, the orientation of spaces to the qibla, and even the knockers of outdoor doors. In the light of this, the purpose of this study is first to assert the concept of "Turkish house", and then its relationship with the religious factors, to reveal this connection specifically to the Islamic Turkish house and to scrutinize the spaces and elements of the Turkish house within this context.
\end{abstract}

Keywords: architectural design, culture, house, Islam, private home, religion, Turkish house.

\section{INTRODUCTION}

House designs in Anatolia (Turkey) do not show stability: that varies depending on time and space. They evolved in time and reached a determined maturity; and also, during specific time periods, it diversified according to different regions. Anatolia exhibits an immense variety in the sense of what is a traditional house. Even in the same region and the same period, there are houses utilized by particular ethnic groups. Eyüce [1] claims that the spatial traditions of societies resist and endure against natural changes. Moreover, he adds that in different regions, societies maintain the same spatial tradition via the traditional Turkish house; however, within the same region, physical witnesses of different cultures stand side by side, such as a Greek house and Turkish house in Western Anatolia. This also strengthens the idea that the origins of the Turkish house lie in their religion, Islam, although climate or geographical factors have an influence. In light of this, our study focused on the basically traditional Turkish house, without discriminating any region and time period. It tried to reveal the connections of religion and house first, and of Islamic beliefs on the traditional Turkish house specifically, in any region and time period. In other words, the given examples of traditional Turkish house in this study may belong to any region in Anatolia and any time period, from the 16th to 20th centuries. Looking at this study from this perspective should be more apposite. Plus, in this study the traditional Turkish house is not handled with the whole of its characteristic features, this would require comprehensive research. The house, its 
spatial organization, the vertical and horizontal relationships between the street, open, semiopen and closed spaces, and architectural elements shaping these relations, will be explained in the context of Islamic beliefs. It is difficult to dissociate completely if an architectural element is formed depending on just Islamic beliefs, or some other factors have a role. For instance, the organization of the traditional Turkish house, the units lining up around a main space, reflects a section of Turks in the nomadic period. For the reason that women in Islam should be segregated from the others, the spatial order is shaped depending on that belief; however, it is so difficult to claim that the courtyard as the main space mentioned above is arranged so for just Islamic beliefs. Physical aspects such as topography, geography, climate, or social and economic factors are also impressive. Within the context of this study, the spatial organization and architectural elements which are affected directly by Islamic beliefs will be scrutinized.

\section{RELIGION AS AN INFLUENCER OF HOUSES AND SETTLEMENTS}

The Turkish houses and the criteria for their "design" were naturally different in the past than today. While the focus in the past was limited technology and materials, climate, forces of tradition, lack of economic supplies; today the concentration is more the economic, technical and aesthetic factors [2, p. 59]. The house is mainly a product of the shelter requirement; however, this concept, handled by different cultures or groups of people in time, shows diversity all over the world.

The effect of culture is not denied to the creation of dwellings and settlements. A house is not only a structure, but also a cultural issue of which its form and organization are influenced by the cultural milieu [2, p. 46]. According to the basic hypothesis of Rapaport, the form of the house is not affected by physical forces or any single factor but is the consequence of a whole range of socio-cultural factors, and the house form is a choice among existing possibilities. Moreover, the greater the number of possibilities, the greater the choice [2].

Provision of shelter can be the passive function of the house, then creating the one best suited to the lifestyle of the people or a basic social unit of space can be following a purpose. According to this view, religion also can be thought of as the basic cultural aspect affecting the house and physical environment.

\subsection{Perception of house in terms of the religious perspective}

The discussion about the relationship between religion and architecture basically starts from cosmic perceptions. In traditional cultures and societies, geometries and symbols shape the physical environment and the people's world. The circle symbolises the impeccability of God and is a representation of eternity; the triangle, the consciousness of the human being; the hexagon, celestial things; the square, the earth and materials [3].

Eliade [4] reports that "exactly like the city or sanctuary, the house is also sanctified in whole or part by a cosmological symbolism or ritual" because the dwelling or house is a representation of an imago mundi. As another view, Eliade also claims that the first territories to be inhabited were created imitating the work of Gods and cosmogony [4]. The beliefs about the birth-death cycle, rebirth, eternity or afterlife reflects into the space, specifically to the house as a world and the cosmos of human beings. In some cultures, the upper parts of their constructions are considered sacred, representing the communication with the transcendent; thus, in some beliefs cosmological rituals are transferred into the chimneys, which are either removed or broken, or being built with an aperture in the roof as called the "eye of the dome". 
In some communities which are deeply bound up with traditions, the effects of beliefs or main perception of cosmos can be traced as the main aspect in the shaping of their environment. For example, in Dogon and Bambara of Mali, the symbolism and its reflections can be seen in their environment. The villages are built up with their pairs, in order to represent the heaven and earth. Plus, their fields are laid out spirally, with the belief that the world was created in that shape [2, p. 50]. Some cultures arrange their environment according to the shape of the stars, some the one-day cycle of the sun. These examples are reflections of the symbols and main elements of the cosmos, as related to their form. Thus, not only the religious architecture of modern civilizations, but also houses, simply took over and developed the people's cosmological symbolism in the primitive habitations [4].

Beside the perception of cosmos, some cultural and religious beliefs and taboos influence the organization of houses. In some examples, determined corners or spaces are sacred or belong to a specific person. In Fiji, the east wall is appropriated for chiefs or in China, the northwest part of the house is sacred. In Tuareg tents the entry is in the south, men on the east and women on the west [2, p. 55]. The same spatial division can be read into most Arabian cultures (Fig. 1). Chowdury states that a clear segregation of sexes is seen by the use of divisions, with each part furthermore being provided with its own entrance [5]. The orientation of spaces is also requisite. For instance, according to Islamic beliefs, it is not behoved that toilets and foot direction of beds orientate to the qibla or rooms are preferred to be facing qibla.

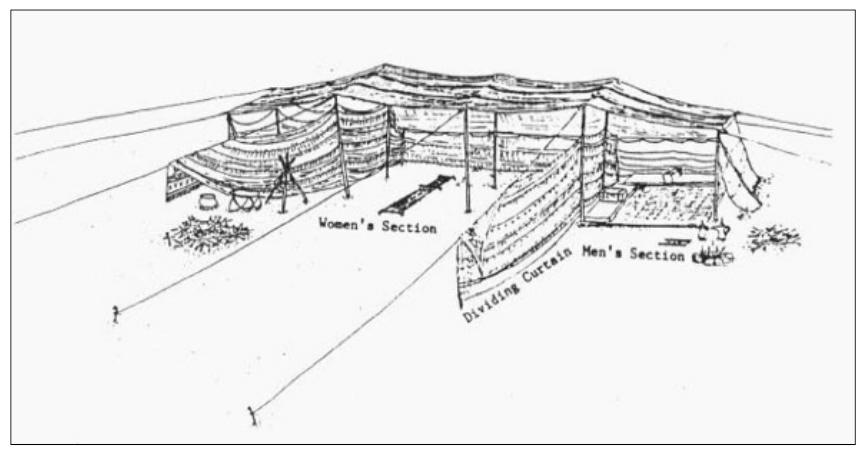

Figure 1: The sexual zones in an Arab tent: women's section, men's section and the dividing curtain [5].

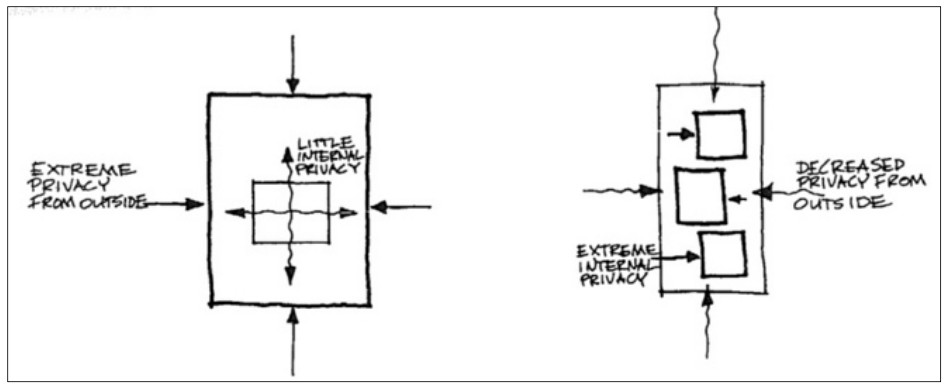

Figure 2: Spatial order and private and public spaces in different cultures - Japanese house on the left, Anglo American house on the right. 
Privacy is the main factor affecting the built environment in many cultures; however, privacy and its interpretations vary from culture to culture. Rapaport [2] emphasizes that in Mediterranean culture, the courtyard and enclosed façades to streets are widespread within the context of privacy for the women. In Japanese culture, the kitchen is seen as the domain of women and differentiates from the other spaces [2, p. 65]. As a reflection of privacy, usage of the courtyard, high walls in the street, and inward spatial organization can be seen in the houses. Even if the privacy concept is the same or the aim is a cloister of people, there are many different alternatives or solutions in different cultures. For example, in India each house is surrounded by a low wall and the house elements are arranged around a central court; while in the Japanese attitude, the house is isolated from the outside world by a high wall or fence, and inside the fence there is little concern for privacy [2, pp. 66-67] (Fig. 2). There may not always be a physical barrier to supply privacy. For example, in a nomad tent of the Middle East, the women's and men's sections were located around the fire in the middle, without a border. Plus, in Malaysia the main house section and kitchen part is separated by an elevation difference, in order to prevent visibility.

Not only in the early period or traditional culture, but also modern era, privacy is paid regard by architects. In her book, Colomina [6] considers the spatial separation in modern house via the views of two modern architects, Loos and Corbusier. The tools of seeing and seeming in the house are basically windows, doors and walls; secondly, through elevation differences, stairs, thresholds, ramps, and so on.

In conclusion: privacy, not only by segregation of women, but also the isolation of the family members from the others, have a great influence on the built environment during the whole historical period, from nomadic to modern and contemporary. In the Turkish house, it can also be said that the most effective factor is privacy.

\section{IN ISLAM}

In Islamic societies as the other ones, religion plays a significant role in shaping the house and the environment. This is because religions describe a way of life; organizing the daily life rituals or banned behaviours, and so on. Considering the Islamic approach, privacy and orientation can be thought of as the main affecting topics. The basic spatial organization of the house, near environment and architectural elements of the house, will be handled in this study from this frame; however, economization or in other words avoiding exaggerated costs, and purity is also paid regard in Islam. Waziri, who focuses on the influences of Islamic beliefs on the contemporary design criteria propounds items: privacy, economization, perfection, avoiding exaggerated costs, houses with many rooms, rooms facing the qibla, locating the lavatory appropriately, the banned usage of lion silk for decoration, the banning of animations, banning of gold, silver pots in the dining rooms, more lower buildings, and separating men from women by sections [7].

\subsection{Women, privacy and house}

As a family construction aspect, the position of women in the house and how they are differentiated in different cultures is so important that it shapes the house backbone. The house is a world of women who should be segregated from the public eye; and the man is outside and related to the public realm or would host his guests in the public spaces of the house. Special guest spaces are very widespread throughout the Islamic world.

In order to provide privacy, Chowdury [5] sorted some common rules in Islamic houses:

- Minimum of windows toward the exterior;

- Screened windows, which allow women to look out without being seen; 
- Indirect entrances to dwellings, usually from a corner, with separate entrances for women;

- High roof parapets to allow private use of roof space.

These principles are mostly overlapped with the design criteria of the traditional Turkish house that will be explained in the next section.

Purdah is also the most known tradition about the women is Islam. It generally means the separate world of woman from the others both by physical and social means. It determines women's role, position, status and daily life activities in the society, by social means and private-public spaces, house and spatial organization in physical terms. The concept of purdah, literally means curtain and both refers to the covering of the body and face, and the physical segregation of living spaces [5]. In a sense, purdah brings privacy and special space.

Privacy has been a very influential concept for shaping the physical environment in every culture, even for non-Muslims. In Muslims, if privacy is considered at a city scale, it can be seen that some cities or towns are divided into neighbourhoods. Moreover, in some of them such as old Sam, there are walls constructed between districts. In China, Muslim houses were closed to the street with walls and had open central spaces [8].

\section{TRADITIONAL TURKISH HOUSE}

For many years it has been debatable what is the "Turkish house," which period it involves, why it is called "Turkish," etc. Turks as a race have existed for centuries before they adopted Islam; however, they had not been in Anatolia and not settled. Their culture and traditions changed after Islam and settling into Anatolia. Therefore, there is still a debate about which houses are defined as a Turkish house. Some approaches tend to define them as an "Ottoman house." Kuban [9] states that the scope of this is broad, and involves political and ideological thoughts due to the reason that Ottomans dominated the area expanse. Therefore, indeed after Turks became sedentary and adopted Islam, the synthesis of both Anatolian and TurcoIslamic factors shaped the house. Turkish house definitions limit the scope and features. Kuban [9] defines the Turkish house with "hayat" as a house whose usage scheme does not differentiate according to regions, was shaped by religious precepts and its history lies back four centuries ago. This type of house lost its main characteristic space "hayat" in time, and this space was included in the inside of the house as the "inside sofa" in late examples. Hayat in a sense means a transition space between the rooms and street; however, it includes much more meaning than this definition. It is the place where the whole of life passes through. Within the scope of this study, the debates and different attitudes against the definitions of the traditional Turkish house will not be discussed. The production of houses within the boundary of Anatolia that were constructed by Turks are accepted as traditional Turkish house.

\subsection{Introverted and central organization: nature inside}

Undoubtedly, the most indispensable result of Islam on the Turkish house is introverted organization. Moral satisfaction and the search for inner life are adopted both from Islamic beliefs and from Middle-eastern precepts. Social synthesis that compounds these two brings an introverted life experience and limited exterior solutions [8]. This is preferred for not only hiding the women, but also the effort of Turks to create their own private environment. Throughout history, all civilizations used a similar form or organization in their built environment. It can be said that the basic geometric organization was repeated in different cultures and milieus, for different aims. Basically, two primary elements played an important 
role in the spatial organization of the house among many civilizations: the Turkish revak, portico or gallery in other words, and the semi-open spatial opening towards the courtyard called the Turkish eyvan, Prostas in Greek, Tablinum in Roman [9]. The combinations vary depending on the relationship of these two elements with the courtyard or an open space at the centre. Arabian bayt, Hittite hilani, the Mesopotamian tarma house and the Turkish hayat house all involve a courtyard and semi-open space covered flat over related to open space.

Küçükerman states that the features of social and family relations in the nomadic period transferred to the settled period and form the organization of the house. The tent, dwelling unit of the nomadic period, was used either communally by family members or in a cluster, and adjacent each other is seen the order that independent rooms in a negligible relation to each other are opened to the "sofa" or "courtyard" by a single opening [10, p. 49]. The main scheme of the Turkish house seems to be a cluster of tents (Fig. 3). The hierarchical relationship between the hayat/sofa and rooms did not change for centuries in the traditional Turkish house, as the result and synthesis of Islam abstraction and nomad culture.

In a sense, the traditional Turkish house was designed for women, providing working areas, leisure and social relations for her. It was the micro-cosmos of the woman. Some of the main daily activities in the household of the women were: cooking, baking bread, sewing, washing; however, in small towns some activities such as drying fruit, cutting firewood and animal husbandry can be added [9, p. 20]. These actions or daily life rituals did not change from the nomadic period along through history until the modern period, and the time when women also took a place in working life.

In the traditional Turkish house, the exterior life is created inside the borders of the house. Nature is let inside the house and recreated in the garden or courtyard, such as heaven with a water unit, fruit trees, etc. Living close to nature has been the Turk's significant philosophy of life inherited from their ancestors and Islam. The reflection of this precept can be seen in the importance given to the open spaces of the house, such as the courtyard garden or sofa.

The result of Islamic precepts can not only be read in the physical environment. The purity of the houses is through the expression of poverty of the human being in the face of Allah's power and magnificence. With this, the exterior walls of traditional houses are represented as white or colours of nature without ornaments, especially in early examples.

The orientation of the house is a requisite, in Islam. Toilets and beds in the rooms are not positioned in the north-south direction, because of the presence of qibla in the south.

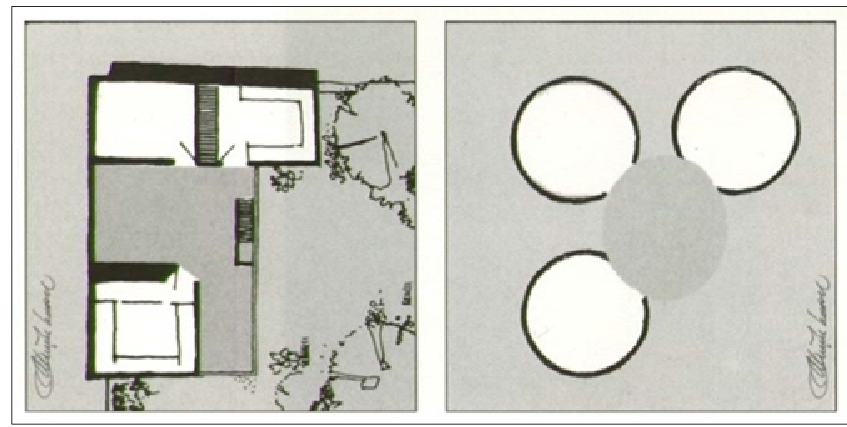

Figure 3: Comparison of life in a tent and in a house. Both share similarities in the arrangement of living units and the common area. The relationship between the rooms and the sofa in the house is the same as that between the individual tents and their common area [10]. 


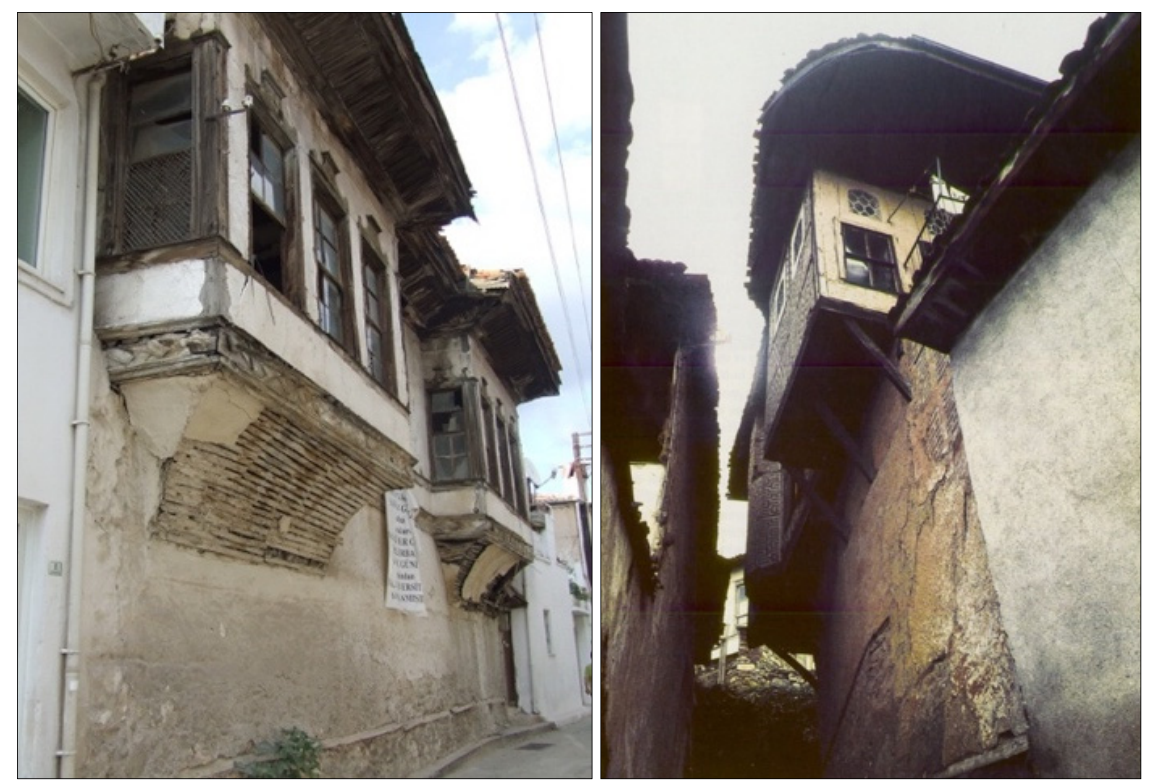

Figure 4: The blank façades at ground level, projections trying to make visual connection with the street and cages covering the windows for privacy, left one from Muğla, 2010. (Source: Güven Ulusoy, personal archive.) The right one from Bursa [10].

\subsection{Privacy and segregation of women: harem and selamlık}

The basic and most common characteristic of the house is that the ground level walls make a distinct barrier between the interior and exterior, in order to supply privacy [10, p. 48]. Mostly, there is no opening except the main entrance door or sparsely pierced windows and the height of the walls vary in different regions, for other factors (Fig. 4).

Men in the towns of Anatolia spend time outside the house for work, going to the coffeehouse or farming. Thus, the house becomes the whole world for the women. She creates nature inside the street walls, mostly in the courtyard or garden. For privacy, the entrance doors from the street and garden do not see each other, in most examples. On the entrance doors, iron mallets are located for guests. Moreover, in some examples they make different sounds for guests, depending on their sex.

The oldest person among the men has considerable privilege, in the house. This creates a sharp distinctive separation in the spaces. The most attentive space is segregated to men, mostly for hosting his guests. These spaces are called "haremlik" or women's quarter and selamlik (men's quarter). Essentially, the selamllk is accessible from the main staircase or street. Haremlik is a place one cannot directly access. In some examples, these spaces have entrances even from different streets or different entrances from the same street. Because the woman is secreted from the guests of the house, it is difficult to serve treats to them. In order to serve from the harem quarters to a selamlı space without making the woman be seen, there is a revolving cupboard designed, in some examples. The plates, tableware or cups used for serving the food, coffee or syrups were placed on the shelves of this revolving cupboard, which was built in a cabinet with the doors opening to both sides. After turning of the system manually, anything on the shelves can be reached from the selamlık [11] (Fig. 5). 


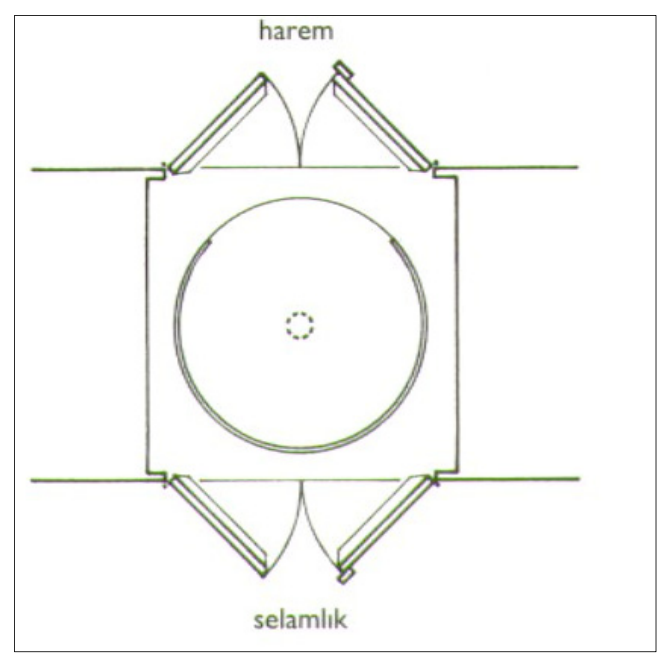

Figure 5: The revolving cupboard which provides the service of food and drinks between the Harem and Selamlık [11].

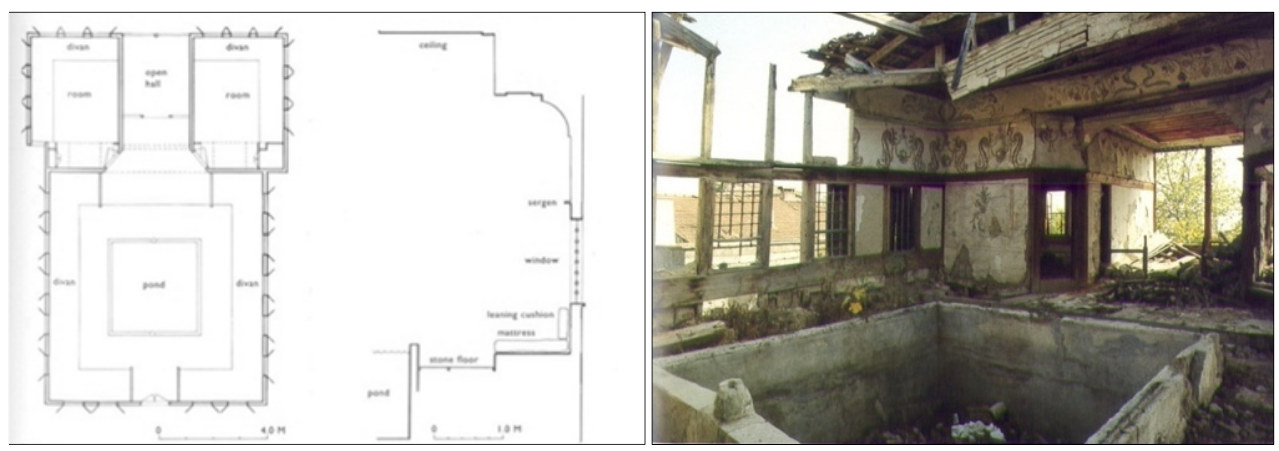

Figure 6: The plan, section and view of a house from Safranbolu northern region of Anatolia showing the order of a selamlı pavilion, with the pond at the center [11].

More qualified houses have a selamlı pavilion in their gardens, in addition to one or two rooms. The entrance of the room is mainly from the street by one entrance and it directly opens to the garden. This room has a pond at the center of the room and is surrounded by divans, may have a fireplace, aiwan between the rooms (Fig. 6).

In some other Islamic cultures, there are spaces called "mardana" and "zenana" just as our haremlik and selamlı. Mardana are where men spend most of their time, relax and host their guests and is accessible from the street. Zenana, the space of women, is specialized for her doing her household work, taking care of the children [5]. These spaces are also evidence of the Islamic influence in the division of space.

As part of the production of spaces inside the house, the courtyard or garden is sharply secluded from the street by high walls. With a door from the street, one can enter the courtyard that is not paved and has a well, fountain or small basin, probably some fruit trees. 

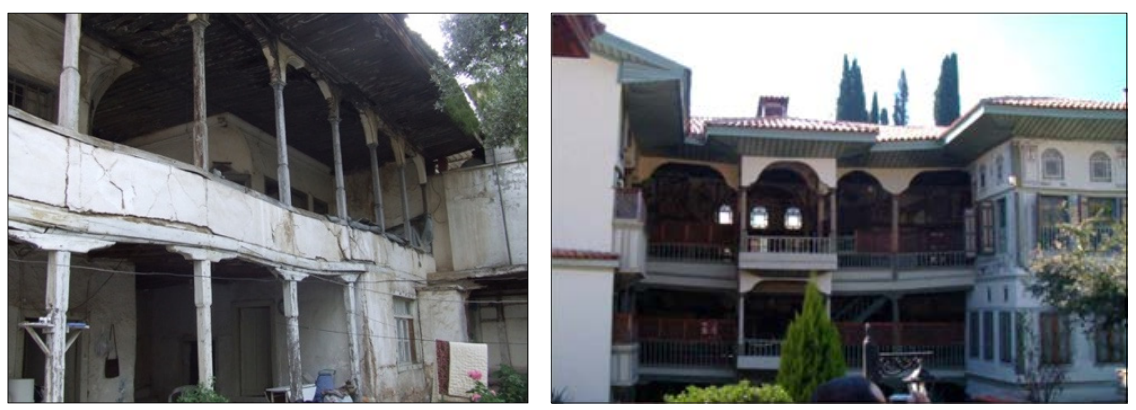

Figure 7: Photos showing the semi-open spaces called aiwan and hayat/sofa. Left is from Muğla (2010), right from Birgi Çakırağa Mansion (2008). (Source: Güven Ulusoy personal archive.)

\subsection{Individual and common: rooms and sofa}

Küçükerman [10] propounds that the traditional Turkish house is constructed and organized with one storey; however, the number of storeys rise through time. On the other hand, he also claims that the first floor of the house involves the stable features of the traditional Turkish house even if the climate, region or geography differentiate. One can read from the first floor the main scheme of the Turkish house, without the effect of physical factors. In contrast, Günay [11] alleges that most of the houses have at least two storeys and the upper storey is for living, while ground floor has service spaces.

By stairs from the courtyard or hayat, one can reach the first floor. This main floor is not a secluded environment: on the contrary bold projections and a number of window rooms are reaching out to the street, so that women could see the street. Windows have wooden screens in order to hide from the passers-by in the street [9].

\subsection{1 "Life": sofa}

The common spaces between the rooms are called many names. It is the most important space forming the traditional Turkish house (Fig. 7). In the early examples, it is seen as a semiopen space, whereas in the late ones it is closed and the number of combinations increase. Exactly like the cluster of tents and their common space, sofa links the rooms or units of the house. As a common space, it has many specialized pieces of furniture.

According to Kuban, the rib of the traditional Turkish house is hayat. It is not only a circulation area, but also a living space especially designed for women. In Turco-Islamic culture, the number of members compose the family structure. The son of the house continues to live in the house with his wife. Each married son utilizes a room with his wife or children. Therefore, a traditional house has adequate room for the whole extended family. For this reason, each room in the house is installed with sufficient requirements for one family. Plus, the house has the flexibility to add rooms to the main organization.

\subsubsection{Units: rooms}

The most striking characteristic of the room in the traditional Turkish house is that each unit is independent from the other spaces. This feature can directly be associated with the tent. As in the nomad's tents, each room is a milieu for sleeping, eating, working and sitting. Küçükerman [10] sums up the basic principles of rooms as independent units serving specific 
functions, the arrangement of its interior following definite social principles, aligned around a common single utility area and finally, with changeable features of common space according to several factors. The patriarchal family system leads the room to satisfy in one, all elementary family needs. The place to unite all family members together is the sofa. The whole rooms have the same size. Dimensions can change; however, the features stay the same because of the unchanged traditional lifestyle of the society. Besides, they are designed flexibly, so the organization can change. In the simple form, they are a sleeping area at night and a living, cooking and dining area all day long; just as the nomadic tents rooms are divided into some functional areas (Fig. 8).

Entrances to the room from the sofa are designed at the corner of the room, to indirectly supply privacy. The rooms are mostly rectangular and divided into two unequal areas; a smaller entrance and service area with a lower ceiling than the other part, called sekialt, where cupboards and perhaps the fireplace are located. The other is a sitting area called sekiüstü, surrounded by low-lying, built-in divans or sedir, and it has a higher ceiling with numbers of windows opening to the street [9] (Fig. 9). Raising the floor of the sitting area by one step separates the spaces. This separation can be associated with religious factors, such as cleanliness and hygiene. The slippers or shoes are left in the sekialtı as a preparation place and the sitting area is made more clean and special. Within this separation, the main space of the room, sekiüstü becomes square. In some examples, this division is supplied by some wooden studs and this strengthens the level difference (Fig. 8).

Sedir wooden furniture, which is mostly constructed in conjunction with the wooden structural system of the house, serves the purpose of sitting. It can be said that via level differences in the rooms that are specialized, more clean and private sitting areas are created. The sedir is mildly elevated from the sekiüstü and associated with the windows mostly being located in the projections to the street (Fig. 9). Room windows are latticed by a wooden cage system in some examples, in order to conserve the women's privacy on the first floor.

Inside of the house, ornaments and figures are used in woodworking. According to some sources [12], the floor of the house is sacred; because of the namaz ritual of Muslims, especially for women who cannot go to the mosque for namaz. Because women touch their forehead to the floor in this ritual, floors are decorated attentively and cleanly.
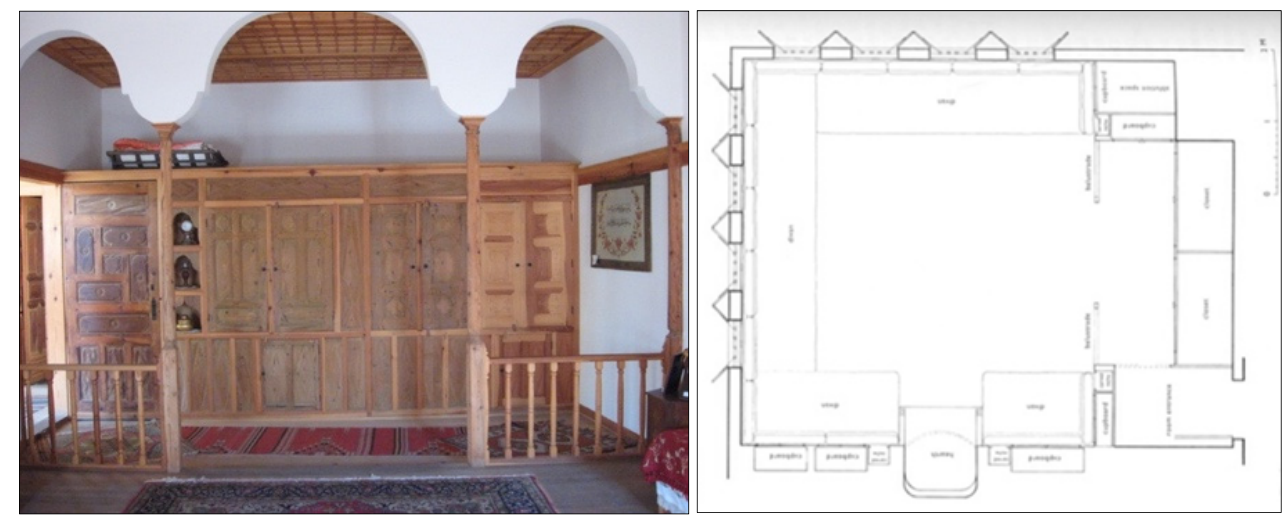

Figure 8: (a) A photo showing the sekiüstü and sekialtı spaces in a room with a cupboard, detailed ceilings, wooden studs direklik with three arches, from the Muğla Özbekler House. (Source: Güven Ulusoy personal archive, 2010.) (b) The plan of a room with its usage from Safranbolu. 

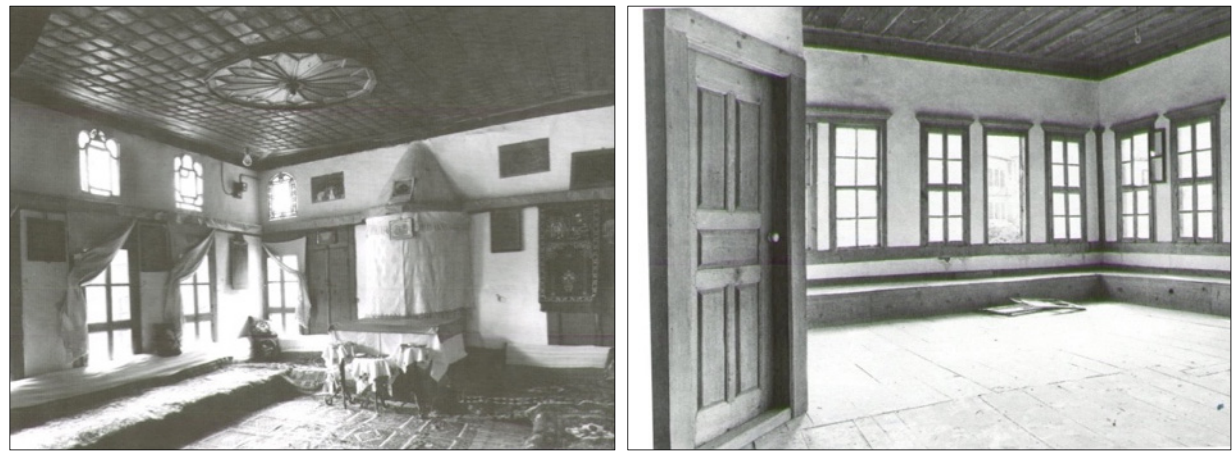

Figure 9: (a) A photo from a house in Göynük showing the specialized spaces and elements of the room: the divan called sedir in front of the window to perceive the street from first floor, with upper windows to let the natural light into the room, a ceiling made a detailed woodworking, a fireplace and horizontal divisions on the walls [9]; (b) A photo from the sofa of a room in a Safranbolu house, showing the door of a room, windows opening to the street and a divan in front of the window [11].

In the traditional Turkish house, the toilet space is not located inside the house, but is placed in the garden; however, bathing mostly takes place inside each room. Following Islamic beliefs, ablution should be performed five times a day, before each namaz ritual. Moreover, in Islamic culture, ritual ablution of the whole body is an obligation for some conditions. In order to create intimacy of the private life of a family, ablution spaces are inside the rooms. There are washrooms or specialized places inside the cupboard. A washing place called Gusülhane is hidden in the cupboard complex. The floor of the gusülhane or bathing cupboard is covered by brick or durable materials.
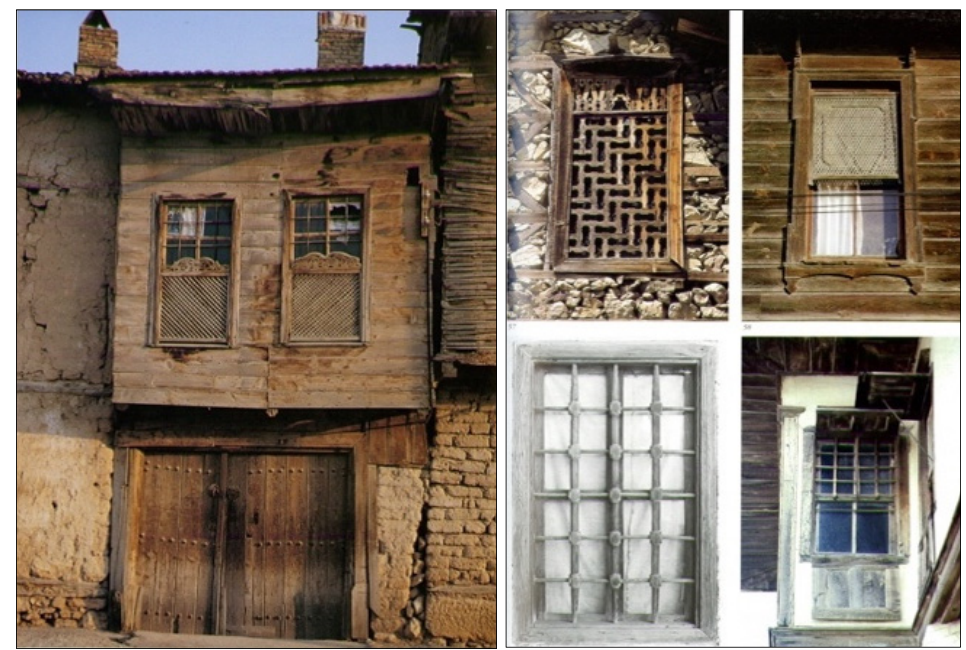

Figure 10: The privacy components of the house first floor: latticed windows with cages and different wooden crafts left from Isparta [9], right [11]. 

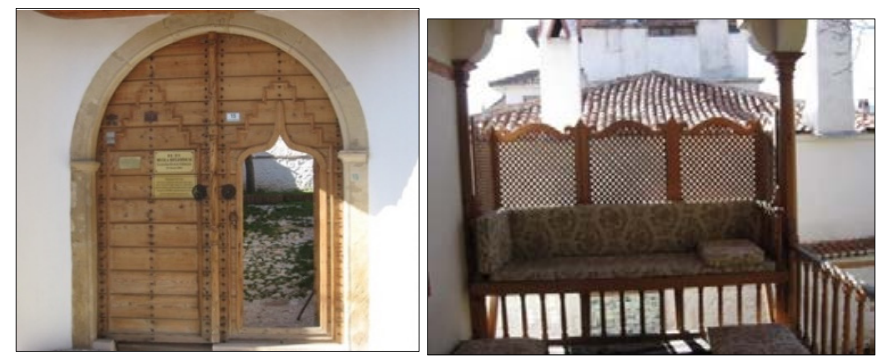

Figure 11: (a) The privacy components of the house: the kuzulu kapı of the Muğla house that enables entry of people and vehicles from different openings and strengthens privacy; (b) A sitting space in the sofa that enables people to perceive the street from cages by a projection. (Source: Güven Ulusoy personal archive.)

\section{REFERENCES}

[1] Eyüce, A., Mimari Mekanın Oluşum Sürecinde Kültürel Etkiler (Cultural Effects on the Formation Process of Architectural Space). International Construction and Life Congress, Bursa, 2005.

[2] Rapaport, A., House Form and Culture, Prentice-Hall: Englewood Cliffs, 1969.

[3] Canbakal, N., Mimari Konvansiyonlar (Architectural Conventions). Yapı Dergisi, 260, pp. 55-62, 2003.

[4] Eliade, M., The Sacred and the Profane: The Nature of Religion, Harcourt, Brace \& World: New York, pp. 56-59, 1959.

[5] Chowdury, T., McGill School of Architecture, 1993. Online. Available: https://www.mcgill.ca/mchg/student/segregation. Accessed on: 25 Feb. 2018.

[6] Colomina, B., Mahremiyet ve Kamusallık [Privacy and Publicity], Metis: İstanbul, 2011.

[7] Waziri, Y., Effect of Islam on outdoor, indoor architecture of the house, The Islamic Methodology for Architectural and Urban Design, Organization of Islamic Capitals and Cities, Jeddah, pp. 133-140, 1992.

[8] Karasözen, R., Kültürel Değişim Süreci İçinde Türk Konutlarının Mahremiyet Açısından İncelenmesi (Analysis of the Turkish House in Terms of Privacy in the Cultural Shift Period), Eskişehir, Master Thesis, 1993.

[9] Kuban, D., The Turkish Hayat House, Eren Yayıncılık ve Kitapçılık: Istanbul, 1995.

[10] Küçükerman, Ö., Turkish House in Search of Spatial Identity, Türkiye Turing ve Otomobil Kurumu: Istanbul, 2007.

[11] Günay, R., Tradition of the Turkish House and Safranbolu Houses, YEM: Istanbul, 1998.

[12] Minsolmaz, Y., G. Konut Mimarlığında Ekolojik ve Sosyo-kültürel Etkenlerin Analizi (Analysis of Ecological and Social-Cultural Factors in Dwelling Architecture), Edirne: Trakya University, Master Thesis, 2005.

[13] Ragette, F., Traditional Domestic Architecture of the Arab Region, American University of Sharjah, 2003. 